\title{
A Disparity in COVID Numbers: Simulation of Trump v. Obama
}

\author{
Ethan Lee ${ }^{1}$ and Brian Oh" \\ ${ }^{1}$ Crescenta Valley High School, La Crescenta, CA, USA \\ \#Advisor
}

\section{$\underline{\text { ABSTRACT }}$}

Previous studies of excess deaths and infections have come out about the coronavirus during President Donald J. Trump's administration. With President Trump's inactions, funding cuts, and statements underestimating the impact of COVID, there have been criticisms about how President Trump handled the coronavirus throughout his presidential term. It brings about thequestion -- What would the case number of COVID deaths and infections be like if President Barack H. Obama, the prior president, was in office? This study uses an open source Python simulation in order to estimate the number of COVID deathsand infections estimated under Trump and Obama's administration. By doing a case study between the two, these results provide information regarding the number of lives that could potentially have been saved along with potential insight into finding preventative measures to save lives.

\section{Disclosure of Conflict of Interests}

All authors have completed and submitted the International Committee of Medical Journal Editors form for disclosure ofpotential conflicts of interest. No potential conflicts of interest were disclosed.

\section{Introduction}

January 19, 2021. This day marked the transition from the 45th President of the United States, Donald John Trump to the newadministration under the 46th President of the United States, Joseph Robinette Biden Jr. Prior to this shift, there were a large amount of historical events that occurred under the Trump administration, ranging from the validity of the election to the takeover of the United States Capitol. President Trump's term has brought around many controversies and discussions, but there is one particular event that has significantly defined Trump's presidency: COVID19.

In particular, the COVID-19 pandemic and how President Trump has handled the response became a central controversy of his presidential term. It defined President Trump's reputation and leadership capabilities to many of the citizens of the UnitedStates, as many have stated or believed that the pandemic became the primary reason that Donald J. Trump lost the reelectionto serve as President for a second term (Baccini, Brodeur, and Weymouth, 2020; Moore, 2020; Parker et. al., 2020). There aremany who believe that he could have done significantly more to ensure the safety of others against COVID-19, condemning him of downplaying and lying about the severity of the coronavirus along with disregarding the input provided by the scienceand health professionals (Bennett, 2020; Lockhart, 2020; Paz, 2020; Peters, 2020).

Regardless of the politics and leadership, the number of cases of COVID-19 at the end of President Trump's presidency are stark: over 25 million confirmed cases of coronavirus in the United States, with over 400,000 deaths (United States Congressman Lloyd Doggett, 2021). With so many lives lost in the wake of the COVID-19 pandemic, there is much contemplation and discussion needed in order to prevent this from occurring again. Specifically, a large question arises when thinking about how President Trump handled the situation: How different would the COVID-19 
numbers for cases and deathshave been if the pandemic happened during President Obama's presidency? Are there particular policies or measures that could have been existing to ensure that pandemics like COVID-19 would not have impacted the United States as severely?

In this paper, I believe that through looking at President Trump's actions and inactions along with juxtaposing them to the 44th President of the United States Barack Hussain Obama's prior actions, policies, and plans, I are able to provide more insight into the strengths and weaknesses of the United States' pandemic plans. I also believe that if President Obama's measures were implemented, there would have been less than half the number of cases and deaths from the coronavirus thatwe currently are experiencing from the result of President Trump's decisions. The purpose of the paper in the end is to provide a better understanding of the impact of leadership in influencing the COVID-19 numbers, and to consider other possible actions so that we can save more lives in the future.

\section{Literature Review}

The term COVID-19 or coronavirus is primarily referencing the pandemic that is believed to have started in Wuhan, China onDecember 1, 2019, though there is still investigation being conducted to confirm the origins of the pandemic (Areddy, 2020; Mallapaty, 2020). Initially, the COVID-19 strain started as a pandemic, a widespread infection in the Wuhan community. It eventually evolved into a pandemic, as the COVID-19 became prevalent throughout the world (Centers for Disease Controland Prevention, 2020). Many including the United States have attributed the severity of COVID-19's early stage spread to China's slow response (Gingrich, 2020; Walsh, 2020).

While it may be the case that China's response could have prevented the spread of the coronavirus, it is important to also reflect on the discussions and choices that have happened when the United States became aware of the potential threat of COVID-19. Through the actions and inactions that occurred after December 1, 2019 under President Trump's administration, it is evident that the United States, like China, was not ready for the pandemic.

Initially, President Trump has stated that his predecessors, particularly President Obama, was to blame for the lack of a plan to tackle the pandemic (Baker, 2020; Fabian, 2020). This was a claim that was disputed by Ronald Klain, the former Obama administration response coordinator, as he stated on his Twitter, "We literally left them a 69page Pandemic Playbook.... thatthey ignored" (CNN.com Wire Service, 2020). The pandemic playbook, named "Playbook for Early Response to High-Consequence Emerging Infectious Disease Threats and Biological Incidents" details the questions and actions that wereneeded along with each federal agency's responsibilities. As people started blaming President Trump for scrapping the playbook, the White House Secretary Kayleigh McEnany defended this decision, stating that the Trump administration replaced the playbook with their own (Carvajal, 2020). There was not much elaboration on what their plan entailed throughout Trump's presidency, nor even after President Trump contracted COVID-19 did Trump's campaign ever release a full COVID-19 action plan if he was elected to a second term (Moore, 2020).

It becomes evident that President Obama's 69-page guideline was never implemented during President Trump's term. Whilethis is the case, it is important to understand how the pandemic playbook came into existence, along with how much impact would the pandemic playbook have made in order to mitigate the impact of the coronavirus. In order to do so, we must explore the motivation and design behind the pandemic playbook, which all started during the 43rd President of the United States George W. Bush's time in office, along with the alternative choices made during President Trump's term that led to thenumber of cases and deaths in regards to the coronavirus.

\section{President Bush’s Response to the Potential H5N1 Flu Pandemic}

During the summer of 2005, President George W. Bush was reading the book called "The Great Influenza: The Story of the Deadliest Plague in History" by John M. Barry. The nonfiction book examined the 1918 flu pandemic in the context of United States history, explaining the medical significance along with how the pandemic spreaded through troops during World War I. This book became the inspiration for President Bush to notify the top homeland security 
adviser Fran Townsendabout the potential threat of a future pandemic, thus inspiring the creation of a national pandemic plan (Mosk, 2020).

On November 1, 2005, President Bush outlined a proposed \$7.1 billion in spending in order to prepare for the flu pandemic.As a preventative measure in order to prepare for any potential threat that the H5N1 avian flu virus may impose, President Bush released the strategy in case it became a pandemic issue. Outlined in his plan were three main elements:

1. Detect any outbreaks in the world.

2. Stockpile any vaccines or antiviral drugs needed while working towards creating new vaccines for the pandemicvirus.

3. Improve response and readiness on the local, state, and federal levels of the government.

In his speech, he referenced historical evidence, how the 1918 flu pandemic was followed by pandemics in 1957 and 1968and the number of deaths caused by these pandemics. Then, President Bush brought up the recent events of the spread of SARS in rural China, the deaths and costs associated with the pandemic. He emphasized the necessity for such a plan, as history and science only shows that there would be another pandemic coming around (William Natcher Center \& NationalInstitute of Health, 2005).

President Bush would release a 17-page document called the "National Strategy for Pandemic Influenza." The pandemic strategy would cover the national strategy along with three pillars: Preparedness and Communication, Surveillance and Detection, Response and Containment. The strategy outlined necessary steps in order to be prepared for the influenza pandemic, including collaborating with world organizations and nations in order to take preventative measures to ensure thatthe virus does not spread (Homeland Security Council, 2005). This document would become the framework that would helpPresident Obama not only respond to the H1N1 pandemic, but also develop Obama's playbook.

\section{President Obama's Response to the H1N1 Pandemic}

In 2009, the spread of the H1N1 virus in Mexico, known as the swine flu, became a large issue to the United States. With concerns that the virus would spread to the United States, President Obama assembled a team in order to evaluate how ready the nation was to take on the virus, in case it grew to become a pandemic. The scientists found that the United States was not ready to handle a pandemic at the time, and that they were considering different measures such as medical distribution, quarantine protocols, and various other measures to contain the potential spread. In lieu of the discussions, former members of President Gerald Ford's 1976 swine flu response team warned President Obama of the difficulty of discussing the outbreakwithout triggering or causing panic (Obama, 2020).

On April 26, 2009, the United States Secretary of Homeland Security, Janet Napolitano, declared a public health emergency in response to the H1N1 virus, despite the fact that only 20 confirmed cases existed within the United States (Evon 2020). Secretary Janet Napolitano stated that the declaration was needed in order to implement preventative measures, in case the outbreak is severe (Hitti, 2009; The White House, 2009). On the same day, a release of supplies from the national stockpile was initiated, which included antiviral drugs, personal protective equipment, and respirators. Two days later, Obama approved a H1N1 test and confirmed Kathleen Sebelius as the United States Secretary of Health and Human Services - leaderof Obama's health team (Korecki 2020). In addition, the declaration allowed the Food and Drug Administration to issue Emergency Use Authorizations, granting certain unapproved uses of Tamiflu and Relenza, some types of protective facemasks, and unapproved diagnostic tests for the H1N1 strain (Lister \& Redhead, 2009).

By late April, the CDC and the federal government had announced that development for a vaccine to this disease was underway. They had even promised that 120-160 million doses of the H1N1 vaccine would be available by October, when the second wave of infections was expected (Healthline, 2020). Unexpectedly, during the 
development process, the H1N1 virus was taking longer than usual to grow in eggs, which is the standard course of action of producing a mutated form of the virus to serve as a vaccine. There were also mistakes in establishing a proper dose, with the initial procedure establishing two rounds of the vaccine. However, it was later concluded that this dosage was only recommended for children 10 and younger. There were also minor setbacks, some of which resulted from repeated glitches during the manufacturing of the drug (Korecki 2020). Due to these complications, the federal government was only able to make 11 million doses available by the intended date, October 2009 (Fletcher \& Khan, 2020).

On June 26, President Obama had signed P.L. 11-32, otherwise known as the Supplemental Appropriations Act, 2009. Thisprovided $\$ 1.9$ billion immediately and another $\$ 5.8$ billion upon a request by the president which specified the need and usefor these additional funds (Lister \& Redhead, 2009).

In October 2009, Obama escalated the swine flu as a national emergency. By then, the swine flu had already claimed more than a thousand American lives, and millions were infected (Kertsche, 2020). During this time, President Obama signed an emergency declaration that would assist facilities in establishing alternative care sites and protocols for transport and triage. This declaration would fulfill one of two conditions that is required for the Department of Health and Human Services to permit a waiver of section 1135 of the Social Security Act, which would provide healthcare facilities with more leeway on certain restrictions during an emergency (Schnirring, 2009).

Federal officials worked with local and state health officials to incorporate a "blended" public and private sector distributionmethod to provide vaccines to individuals who wished to be vaccinated. However, since the amount of vaccines released were limited, states had experienced some difficulty in getting the vaccine available for distribution. Moreover, the civilian vaccination program for the $\mathrm{H} 1 \mathrm{~N} 1$ pandemic was voluntary, and there were no plans at any government level to require thatthe general public be vaccinated. Nevertheless, requirements for vaccination of health workers were established by some states, private health sectors, and the Department of Defense (Lister \& Redhead, 2009).

By January 14, 2010, the White House announced that the H1N1 virus had been contained after Secretary of Health and Human Services Kathleen Sebelius' public health emergency declaration in April 2009. It was mentioned by Kathleen Sebelius that after reviewing the response, President Obama took correct steps in order to mitigate the harm that the H1N1virus could have caused. As described by Kathleen Sebelius:

"As soon as the HIN1 flu was identified in April, we sprang into action. We developed a safe, effective vaccine in six months-- three months less than it usually takes. Working with state and local partners, we were able to vaccinate more than 60 million Americans in the three months after the first dose of vaccine came off the production line, the vast majority of them in high-priority, at-risk groups. We also launched an aggressive outreach campaign to educate Americans about how to preventthe spread of H1N1."

In the end the Center for Disease Control and Prevent (CDC) reported that 60.8 million people contracted H1N1 and 12,469people died. The World Health Organization (WHO) announced the end of the pandemic by August 11, 2010 (Shaw, 2020).

The Obama Administration did utilize certain aspects of the influenza pandemic preparedness playbook that the Bush Administration had first established in 2005. For instance, significant federal investments were made to expand the production capacity for egg-based vaccines in the case that a flu pandemic arose again in the near future. Moreover, federalhealth officials purchased millions of doses for the H1N1 pandemic flu vaccine as a means to stockpile large amounts of vaccines. In addition, billions of dollars in funds were supplied by Congress to improve vaccine production methods. BrianNaylor, who interviewed President Obama on how the swine flu response was dependent on President Bush's plan, stated that, "The administration got some $\$ 7$ billion from Congress to stockpile anti-viral medicine and improve technology for vaccine production. There was extensive planning and testing of the playbook with an eye toward quick detection and containment" (Naylor 2020).

Furthermore, a joint assessment between the HHS and DHS (Assessment of States' Operating Plans to Combat Pandemic Influenza: Report to Homeland Security Council) found that preparation was most thorough when state 
public health agencieswere responsible for public communications, infectious disease surveillance, and distribution of vaccines and antiviral drugs. Yet, it also found that states had difficulty in planning for surges within emergency medical services and health care, which has been resolved through dedicated federal funding to state and local government only through HHS grants (Lister \& Redhead, 2009).

As a result of the 2009 H1N1 pandemic and the Ebola outbreak in 2014, the National Security Council, under President Obama's guidance, had established the Global Health Security and Biodefense unit, a pandemic preparedness team established by Obama's National Security Advisor, Susan Rice in 2014. In 2015, the Obama administration also announced an investment of $\$ 1$ billion to expand the Global Health Security Agenda to prevent, detect, and respond to future infectious disease outbreaks around the world. It was intended to stimulate investment in infrastructure, equipment, and skilled personnel, as well as empower international organizations and countries to achieve their specific targets and goals through a joint effort. During the Ebola pandemic, the U.S government had also committed to assisting at least 30 countries to achieve the Global Health Security and Biodefense Agenda's targets to limit the potency of the ebola virus (The White House, 2020). In addition, The National Security Council had produced a 70page pandemic playbook that listed strategies and guidelines tofollow in the case of another pandemic. Although it was never formally incorporated into official White House policy, it did address many of the obstacles that the Trump Administration faced during the COVID-19 pandemic (Jankowicz, 2020).

\section{President Trumps' Term: Pre-COVID and Current}

When Donald Trump was elected to become the 45th President of the United States, President Obama and his administration took on the task to debrief and prepare Trump and his administration about the many federal and global issues that they would have to manage. Among the many preparations for the presidential transition that took place in January 2017, Obama'sadministration developed and provided the Trump administration a document titled "Playbook for Early Response to

High-Consequence Emerging Infectious Disease Threats and Biological Incidents." The 69-page playbook provided guidelines to assist leaders in organizing a U.S. government response to a detrimental disease and each step to take (Knight 2020, Karlawish, 2020). Along with the document, the Obama administration provided a pandemic training in which the Trump administration had mixed receptiveness to attending. It was stated that a member of Trump's Cabinet fell asleep during the training, while others wondered why they were expected to attend the meeting (Collman, 2020). This would set thetone for the Trump administration and how they would handle the COVID-19 pandemic.

\section{Prior to the Onset of the Coronavirus in the United States}

Before the emergence of the COVID-19 pandemic, there were already several pre existing components that exposed how theTrump Administration lacked the resources in maintaining a proper pandemic response (Kavanagh, 2020; Farzan, Hassan, et.al., 2020). For one, the healthcare system within the US was heavily underprepared, as medical equipment and supplies werevery limited, many patients also did not have immediate access to treatment due to the surge in the number of infected individuals, and hospitals lacked the ability to isolate all patients, leading to more infections (Chehrehgosha 2020). In addition, the funding mechanisms in place also had a role in preventing agencies such as the HHS from receiving the necessary financial support required as a means to establish a proper response (Keller 2020).

Moreover, the US government had a national mock exercise where, with the participation of multiple federal agencies, they had conducted a mock drill in order to visualize how the nation would handle a pandemic, particularly a deadly global outbreak with no cure. Known as the Crimson Contagion 2019 Functional Exercise, this document had revealed that the nation was not at all prepared, with the hypothetical deaths and infections being 586,000 and 110 
million people, respectively(Marin, Moseley, 2020; Crimson Contagion, 2020). With this in mind, it was no wonder that COVID-19 had a much more devastating impact than originally thought.

\section{Initial Onset of the Coronavirus in the United States}

The Trump Administration first addressed the coronavirus in early January by establishing quarantine orders for citizens whohad recently visited China and prohibited entry to anyone who had recently been in China in the last fourteen days (Shaw, 2020). Despite these measures, President Trump actually downplayed the severity of COVID-19, ridiculing the Democrat's criticisms of his response as a "hoax," claiming that any American can seek a coronavirus test and arguing how the coronavirus is no less severe than the seasonal flu (Facher, 2020). However, it was not until March 13, 2020, that Trump haddeclared the coronavirus as a national health emergency and allowed $\$ 50$ billion to be utilized for aid to hospitals along with more production of tests. This declaration was made after 33 United States governors in their respective states have already declared their own state of emergency regarding the coronavirus (Hennigan, 2020).

President Trump was also reluctant in listening to the urges of Democrats, who pleaded for the President to utilize the Defense Production Act as a means to mass produce much needed supplies to address the advancing coronavirus pandemic. Itwas not until a week and a half later that President Trump had used the act to pressure General Motors to prioritize production of ventilators. Moreover, the United States government's guidelines on social distancing were at first relatively loose, which allowed for some states to not declare lockdowns until April, while other states resisted implementing a lockdown entirely. Still, many states began to follow along with the playbook organized by the Obama Administration, yet it was not until two months after the CDC had confirmed the presence of coronavirus within the nation (Johnson 2020).

By April, many states had adopted pandemic procedures and issued orders for citizens to remain at home. As the CDC alteredtheir guidelines to the public by recommending that everyone wear cloth masks, President Trump openly resisted these measures as he declared that he would not wear masks. This open act of ignorance against the CDC inspired many of his supporters to also not wear masks (Johnson 2020).

This act of ignoring advice from medical experts became a common theme throughout President Trump's response to COVID-19, as he blatantly continued to ignore scientific recommendations and even go so far as to fire his experts. Trump had expressed his wish to fire Dr. Anthony Fauci, who leads the National Institute of Allergy, following a pattern of continuously silencing and attempting to discredit the NIH expert throughout the pandemic. This can be further noted by howa report by the Union of Concerned Scientists has displayed that the amount of press events held by the CDC drastically decreased, with the president leading three-quarters of the 69 events held since the outbreak. (Viglione 2020).

Following May and soon into summer, immense pressure from President Trump and from protestors claiming COVID-19 closures as a violation of their freedom forced 44 states to reopen. It was also around this time when the Senate Majority Leader Mitch McConnell had claimed that the Obama administration had failed to provide any information about the possibility of the threat of a pandemic to the Trump Administration (Knight 2020). However, it was actually revealed by RonKlain, the Obama's administration's Ebola response coordinator, that there was a playbook, which gave a step on step guide on how to respond to pandemics and criticized the Trump administration since "they didn't run the plays" (Bruggeman, Margolin, Mosk, 2020). Even more, the U.S government had launched Operation Warp Speed, a collaboration between the CDC, FDA, and other federal agencies in order to accelerate the development of an approved vaccine, with the goal of producing 300 million doses by January 2021. Many experts had dismissed the operation as being unrealistic, and claimed that the government had policitized the process of the vaccine's development, causing growing public distrust (Johnson 2020).

As the year progressed, COVID-19 cases continued to surge. Nevertheless, U.S health officials and drug makers announced that they were expecting to produce potential vaccines by the end of summer. As of July 13 th, the U.S had reported more than 
3.3 million COVID-19 cases and a minimum of 135,205 deaths (Lovelace Jr., 2020).

By late 2020, with the upcoming election, it was evident where the president's priorities lay as he did not address the enormous upsurge of COVID-19 cases as millions of citizens ignored multiple warnings about the spread of the virus andtraveled to spend with their families, with COVID infections approaching a record 200,000 cases in a day (The Guardian,2020). Instead, President Trump focused during the past November and December with claims of a stolen election, lashing out at members of his own party, and delaying relief legislation until he finally relented into signing the coronavirus relief deal. Regardless of the more than new 6.1 million infections and 74,140 deaths in December, Trump instead focused on boasting how unparalleled the speed of the vaccine development was occurring due to his efforts and also praised his effortson "building the greatest economy in the history of the world" (Macias 2020).

It is evident that President Trump fell short in his claims of how the coronavirus "will miraculously go away" by Easter (Levin, 2020). There were several key factors that led to the United States dominating the world in the number of COVID-19cases, which included: distribution shortages of personal protective equipment, some of which was why caused by the mismanagement of federal contracts; the downplaying of COVID-19 by Trump and his defiant tone against the advice of multiple medical experts, igniting millions of his supporters to follow suit; and an overall delay in response by the United States Government (Dorneaur, 2020; Fitzpatrick, 2020; Yong 2020). In the end, the Lancet Committee on Public Policy and Health analyzed Trump's policies and social schisms and concluded that the United States could have averted 40\% of the deaths from COVID-19 (Lancet Commission, 2021).

\section{Research Methodology}

In this portion, I will first review the actual number of COVID cases that existed during President Trump's term. Afterwards,I will utilize a quantitative measure using a Python simulation provided by the COVID 19 Projections that uses machine learning. It is an open source project created by Youyang Gu in order to create the baseline as to what the simulation would have anticipated Trump's COVID number of cases and deaths to be. Then, I will run the same simulation under specific conditions that I anticipate would have existed based on the actions that President Obama has taken during the H1N1 pandemic, taking the pandemic playbook into consideration as well. By doing so, I will compare these policies and actions toother countries dealing with the pandemic to see which ones have similar characteristics and decisions. This will allow us to find the necessary values to change specific indicators in Python and alter the conditions to have the simulation find the case number of infections and deaths if President Obama was in office during the pandemic.

\section{Analysis}

\section{Trump Presidency: The Real Number of COVID Cases}

In order to generate an accurate understanding of the number of cases and deaths from COVID, the graph below will represent the number of COVID cases and deaths reported in the United States from January 21, 2020 until January 26, 2021, generated from the CDC. It is important to note that while the transition in presidency from Trump to Biden occurred on January 19, 2021, the information must take into account the backlog for testing along with reporting deaths that occur, whichgenerally tends to be more than a week (Chen, 2020). For the purpose of the research, the data has been extended to a week after the presidential transition to account for the impact of President Trump's term in office. 
Figure 1. Trends in Total and Cumulative Incidence Rate of COVID-19 Cases in the United States

Trends in Total and Cumulative Incidence Rate of COVID-19 Cases in the United States Reported to CDC, per 100,000 population

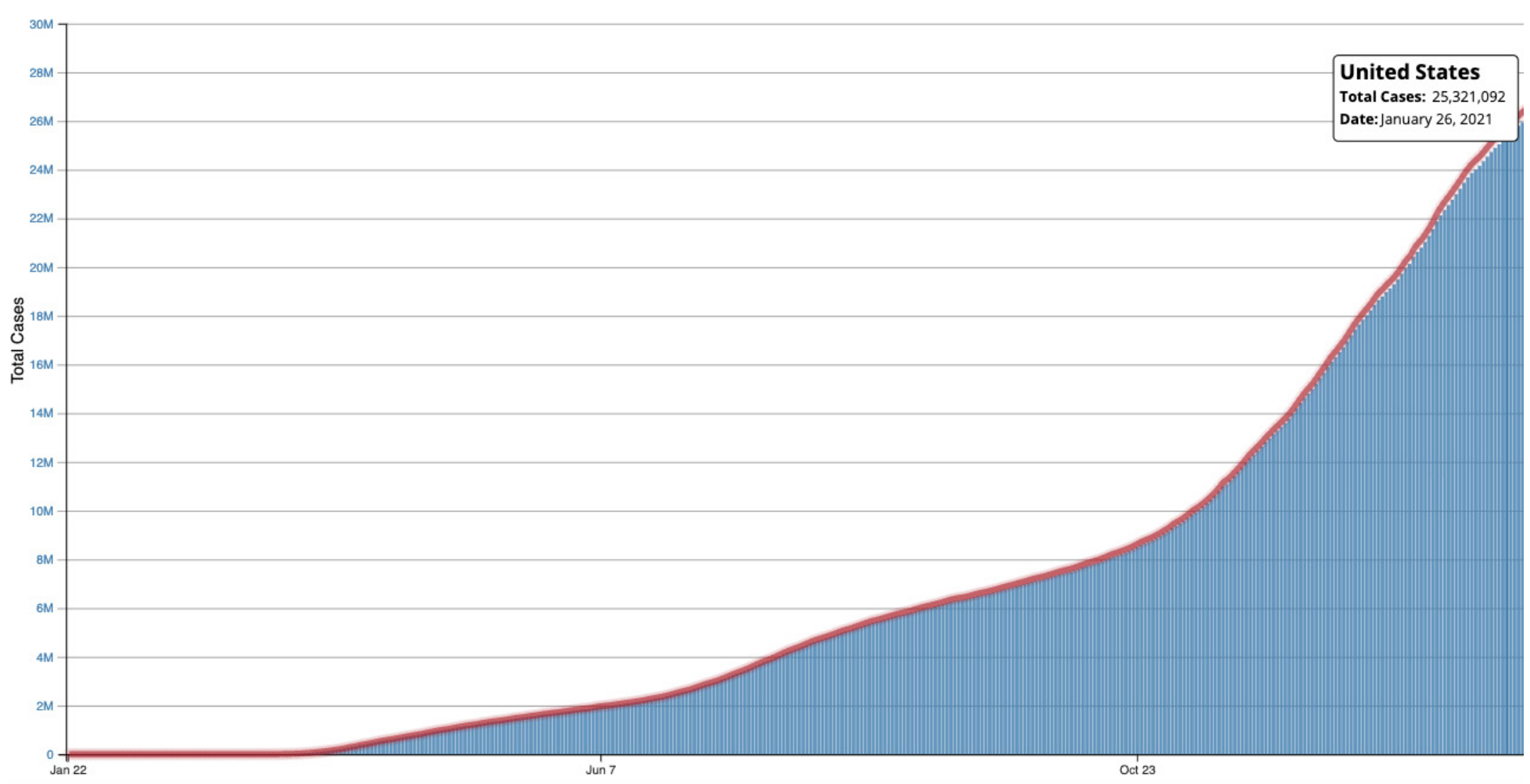

Centers for Disease Control and Prevention. (2021). Trends in Number of COVID-19 Cases and Deaths in the US Reported toCDC, by State/Territory. 
Figure 2. Trends in Number of COVID-19 Cases and Deaths in the US Reported to CDC, by State/Territory.

\section{Trends in Total and Cumulative Incidence Rate of COVID-19 Deaths in the United States Reported to CDC, per 100,000 population}

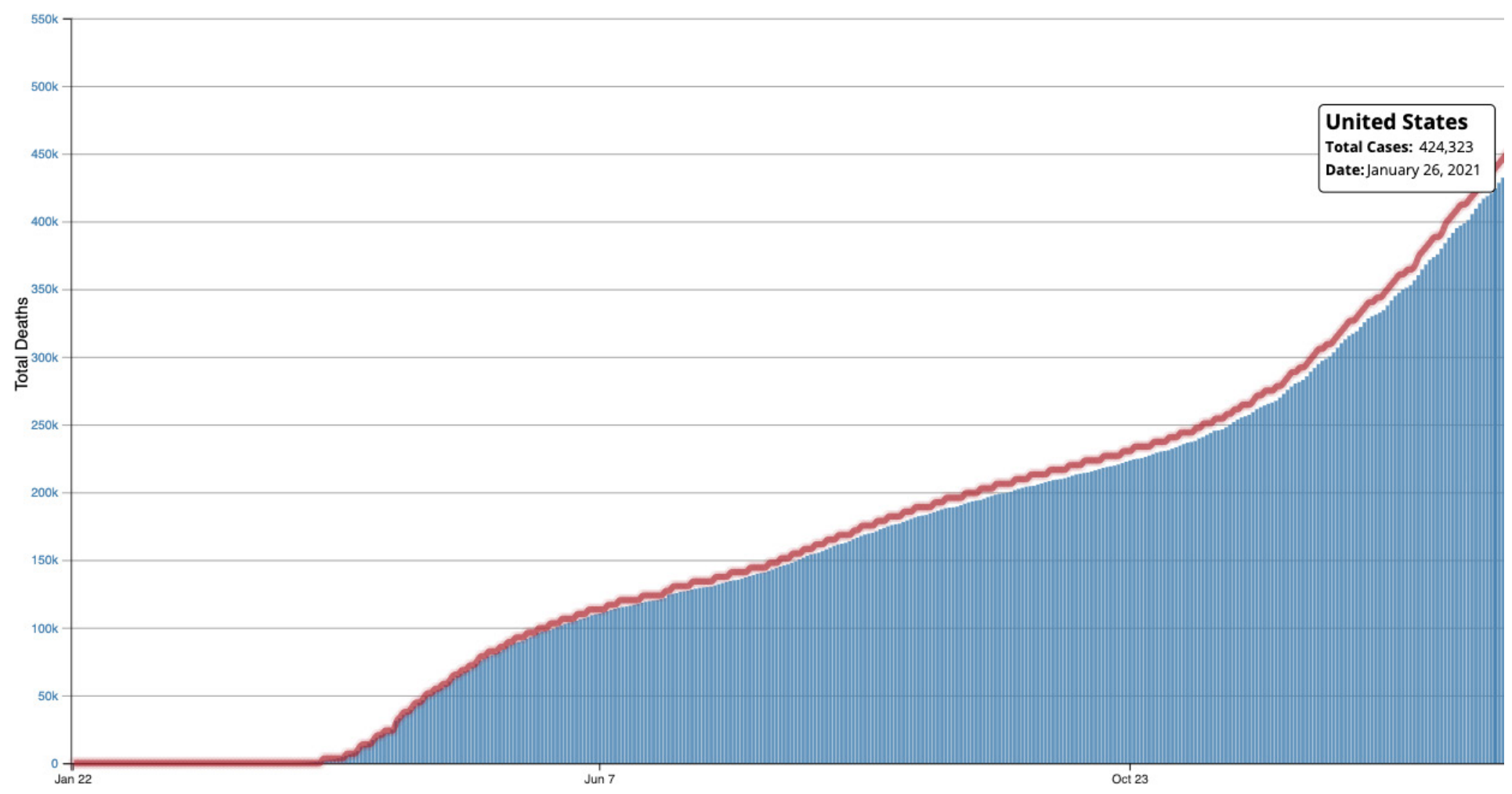

Centers for Disease Control and Prevention. (2021). Trends in Number of COVID-19 Cases and Deaths in the US Reported toCDC, by State/Territory.

During President Trump's term, the reported numbers according to the CDC on January 26, 2021 are 25,321,092 COVIDcases with 424,323 deaths.

It is important to note that both the number of COVID cases and deaths reported by the CDC will be considered underreported. When it comes to COVID cases, it is believed that the number of cases in the United States is likely 3 times the reported number of cases (Haseltine, 2020; Noh, 2021). Due to this reason, I anticipate that the actual number of COVIDcases is closer to the value of 75,963,276.

In addition, it is believed through research that since we are far from herd immunity, the reported deaths in the United States through November 15, 2020 are remarkably more. It is assumed that approximately 35\% of COVID19 deaths are not reported from the CDC, whether due to misdiagnosis, reporting issues, or various other factors (Reinhard, Brown, Thebault \&Sun, 2020; Angulo, Finelli \& Swerdlow, 2021). Due to this reason, I can assume that by including the unreported number of deaths, the true number of deaths from COVID should be around 652,805 .

\section{Trump Presidency: The Number of COVID Cases through Simulation}

While the true number of COVID cases and deaths is available for President Trump's term, I believe that using the simulationprovided by COVID19 Projections Project, a project that provides open source Python codes that simulates the COVID pandemic numbers, allows us to create a benchmark as to what the true numbers may be in the pandemic based on specific indicators. Provided below is the graph that is generated from the open source code and rendered through plotly: 
Figure 3. Cumulative Number of COVID-19 Infections

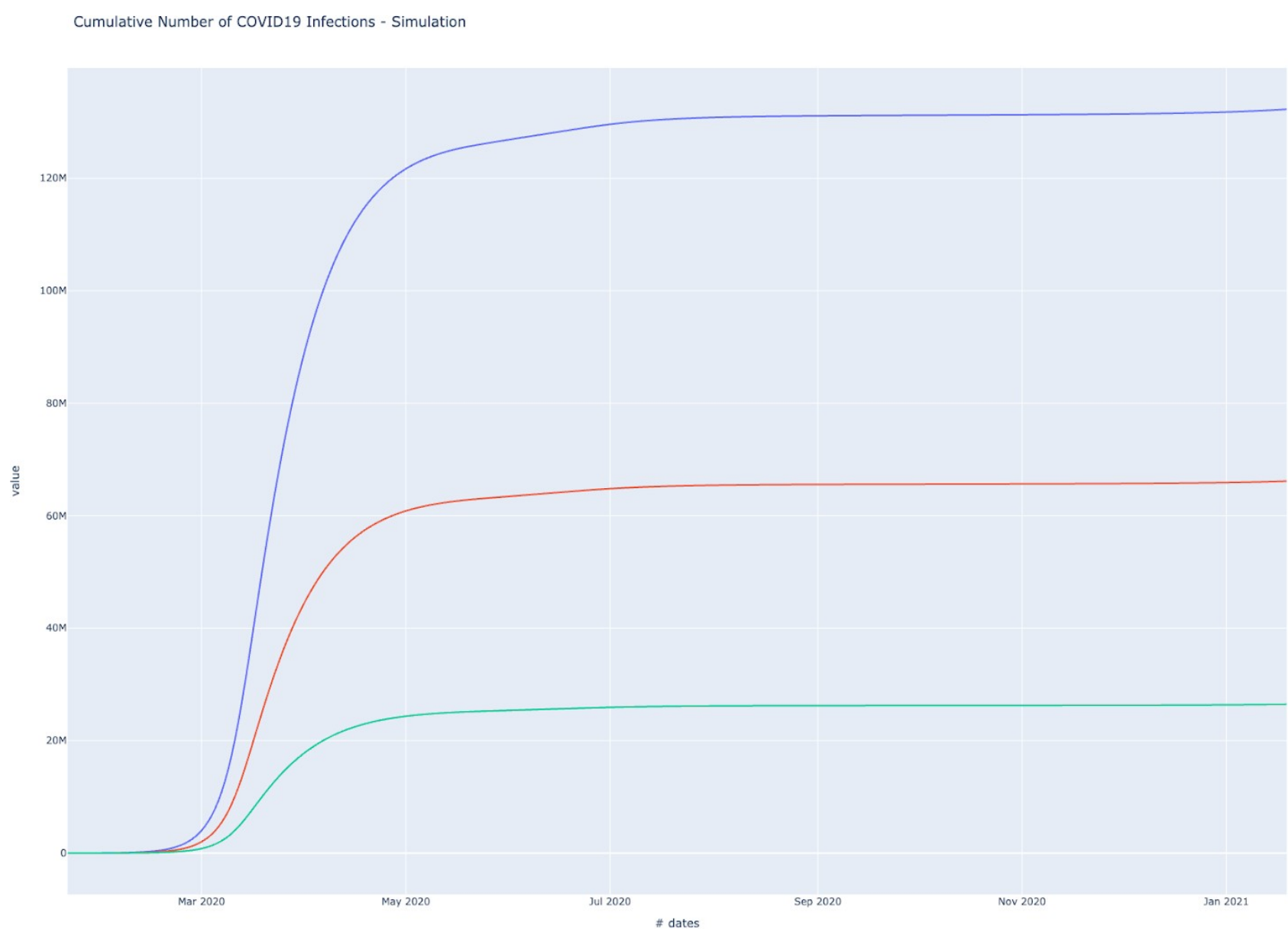


Figure 4. The Cumulative Number of COVID-19 Deaths

Cumulative Number of COVID19 Deaths - Simulation

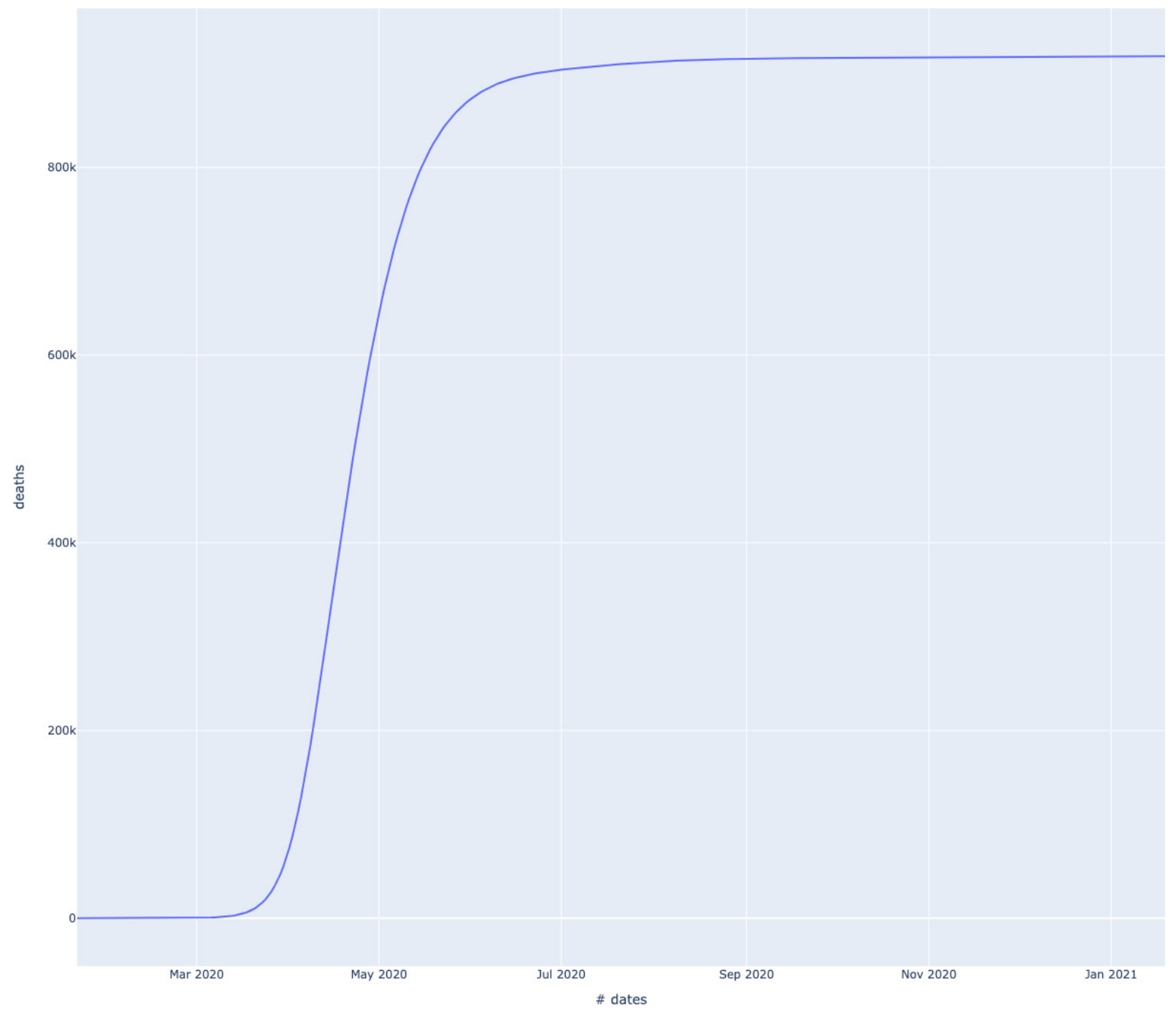

Figure 5. Simulation Default Values

Parameters:

INITIAL_R_0 :

2.2637755302375644

LOCKDOWN_R_0 :

INFLECTION_DAY :

0.9038440070216232

RATE_OF_INFLECTION:

LOCKDOWN_FATIGUE :

2020-03-15

REOPEN_DATE :

0.35245146707754205

1.0

REOPEN_SHIFT_DAYS :

2020-05-10

REOPEN_R :

$-0.1425555065958532$

REOPEN_INFLECTION :

1.2681889965435804

POST_REOPEN_EQUILIBRIUM_R : 1.0073471671122585

FALL_R_MULTIPLIER : $\quad 1.0020627766084023$ 
According to the simulation, the final numbers according to Figure 3 and 4 will be 132,587,883 total infections with 918,871 deaths. Figure 5 shows the default values provided in the simulation that reflect the different indicators considered in the simulation that are regarded as important factors influencing the number of cases and deaths.

While the numbers for both total infections and deaths are significantly larger than the number of cases reported by the $\mathrm{CDC}$, there are specific reasons for these differences. The variable infections in the simulation graph are based on "currently infected" individuals, not particularly individuals that would have been tested for being infected with COVID-19. Due to the incubation period, an individual is considered under the variable "infectious" if the person had the coronavirus for 2-8 days after initial exposure, while those considered under the variable "most infectious" had the coronavirus between 4-6 days. (Gu,2021) Based on this information, the simulation requires that we divide the number of "currently infected" individuals by half, which would be around 66,293,942 "infectious individuals." In order to get "most infectious" numbers, we need to divide the number of "currently infected" individuals by 5 , which would generate around 26,517,577 individuals. When it comes to the number of deaths, the numbers estimated from the simulation will always be greater than the number of probable deaths.

\section{Obama Presidency: The Number of COVID Cases through Simulation}

In order to create the number of COVID cases and deaths that would have existed if President Obama was in office, there arefactors I took into consideration. Not only did I take into account the past actions that Obama has done during the H1N1 pandemic along with the policies and infrastructures that he created in preparation for a pandemic, but I also considered otherfactors such as the characteristics of other countries handling the pandemic.

When generating the values, the main countries I ended up using as benchmarks in order to reflect the potential impact of Obama's presidency were Canada and South Korea. Both countries were ranked in the top 10, with the United States being ranked the highest, during 2019 under the Global Health Security Index, a scale that represents the countries' health security and capabilities (Global Health Security Index). Canada is a suitable comparison to the United States for many reasons - theyboth have similar risk profiles, aged profiles, distance from the earliest coronavirus hotspots, and protocols (Beauchamp, 2020; Coletta, 2020). That being stated, there are particular distinctions to keep in mind, such as population size, population distribution, and medical infrastructures (Austen, 2020; Coletta, 2020; Public Health Agency of Canada, 2020).

When it comes to South Korea, South Korea has been lauded in many news media as being successful in its response to COVID-19. In particular, there have been elements such as the nation's testing capabilities and contact tracing that have contributed to South Korea's ability to contain the spread of the virus. While there are significant differences that South Korea has in comparison to the United States when it comes to culture and perspective on privacy, there are similarities that do exist (Azralon, 2020; Yan \& Babe, 2020). In particular, both South Korea and the United States both recently faced outbreaks - South Korea with Middle East respiratory syndrome (MERS) and the United States with H1N1. Regardless of the differences in mortality rates and transmissibility that exist for both viruses, South Korea and the United States made mistakes in their responses from the past and created stronger contingency plans in the possibility of future outbreaks (Martin\& Yoon, 2020; VCU Health, 2020). This is a specific aspect that made A.R. Shaw, a press reporter who covered Obama's administration's handling of the administration, stated that President Obama would have responded similarly to South Korea when it came to the coronavirus pandemic (Shaw, 2020).

Based on these benchmarks and beliefs, I had adjusted specific values on the simulation to be reflected on the graphs here: 
Figure 6. Cumulative Number of COVID-19 Deaths.

Cumulative Number of COVID19 Deaths - Simulation

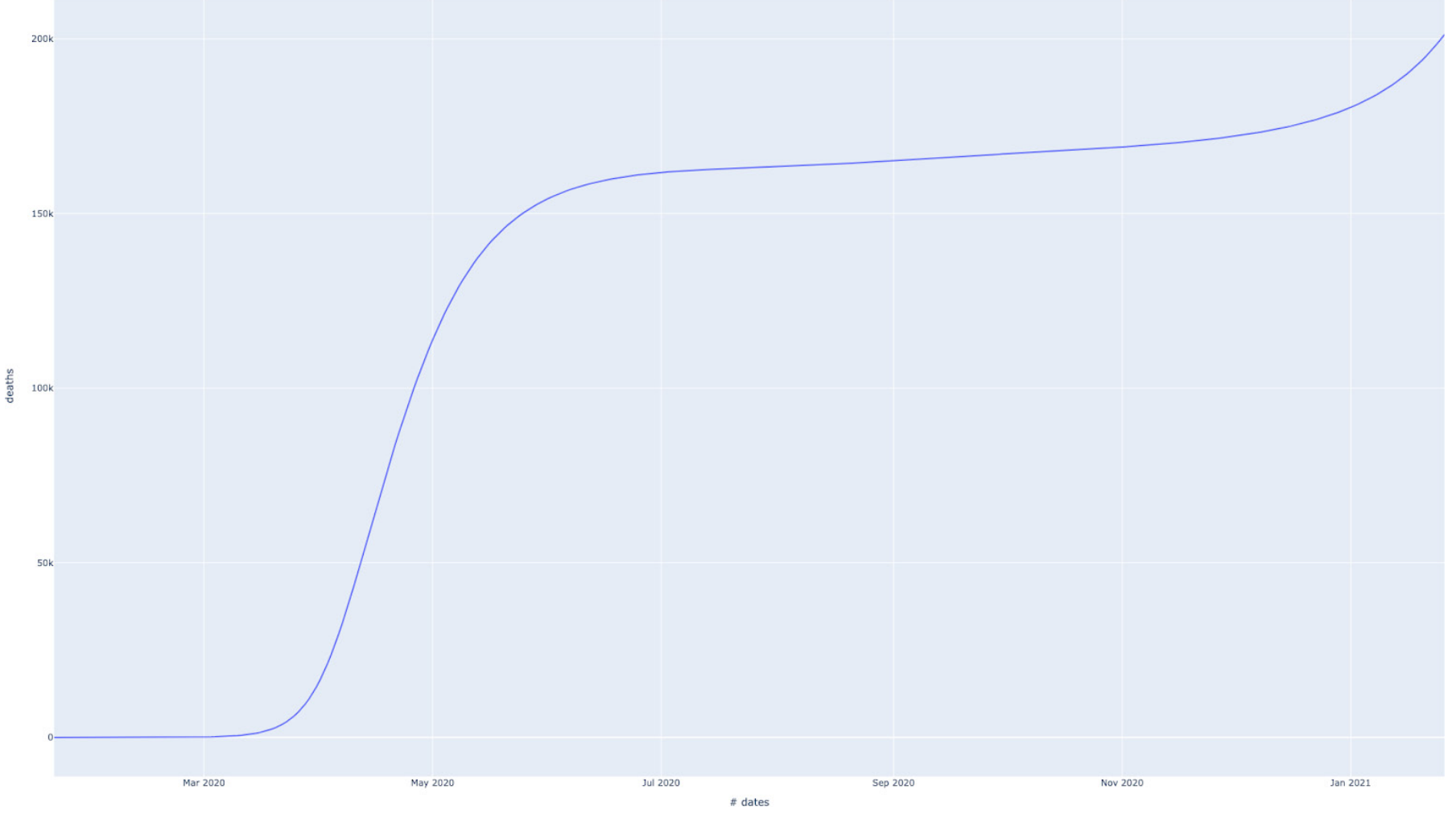


Figure 7. Cumulative Number of COVID-19 Infections.

Cumulative Number of COVID19 Infections - Simulation

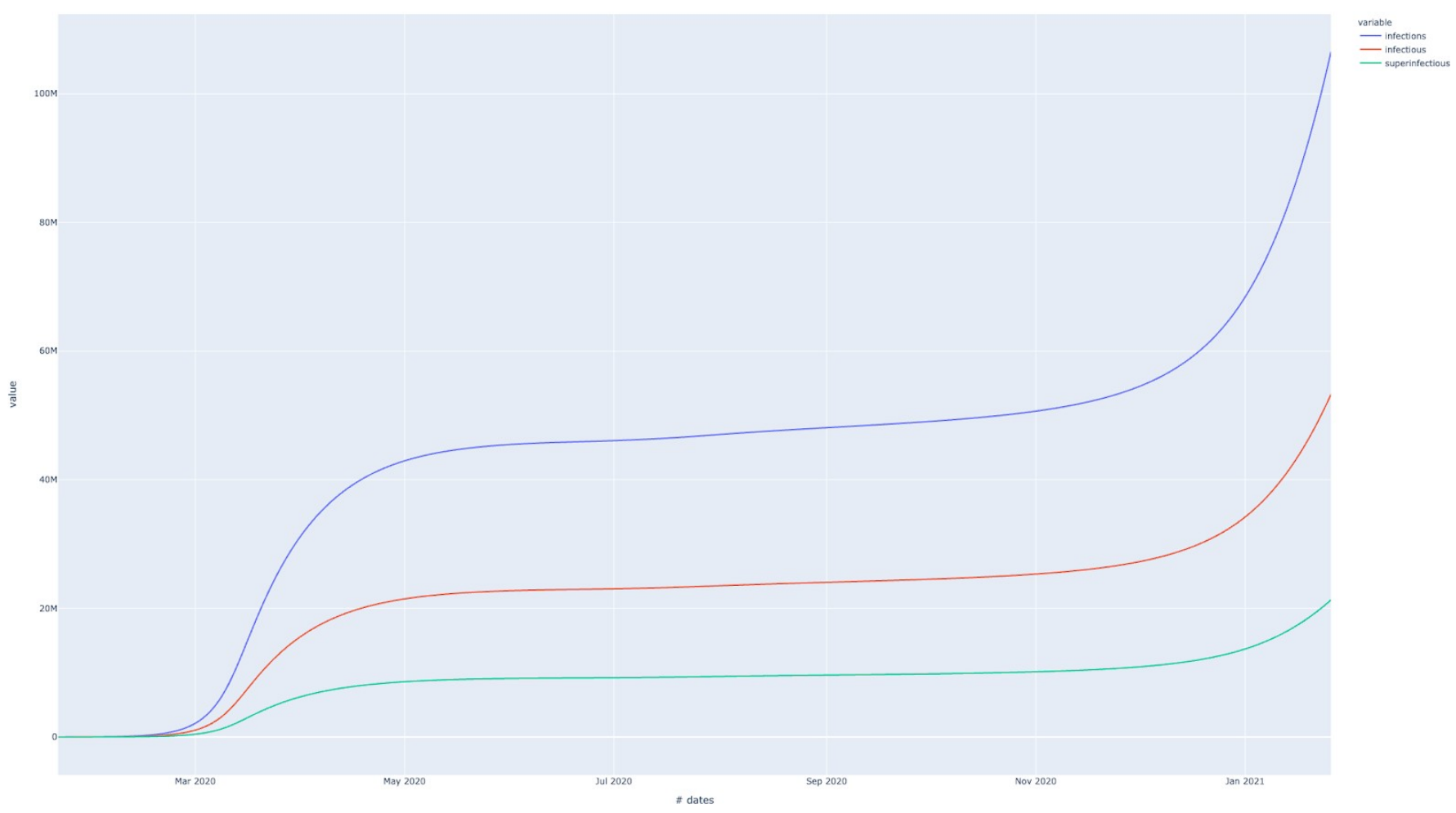


Figure 8. Values provided from Simulation.

$\begin{array}{ll}\text { Parameters: } & \\ \text { INITIAL_R_0 : } & 2.01 \\ \text { LOCKDOWN_R_0 } \quad: & 0.8278547766743376 \\ \text { INFLECTION_DAY : } & 2020-03-15 \\ \text { RATE_OF_INFLECTION : } & 0.35245146707754205 \\ \text { LOCKDOWN_FATIGUE : } & 1.0 \\ \text { DAILY_IMPORTS } \quad: & 1089.8993483065829 \\ \text { MORTALITY_RATE : } & 0.004999999999999999 \\ \text { REOPEN_DATE : } & 2020-05-10 \\ \text { REOPEN_SHIFT_DAYS : } & 29.917149850153365 \\ \text { REOPEN_R } \quad: & 1.2681889965435804 \\ \text { REOPEN_INFLECTION : } & 0.32847835689143956 \\ \text { POST_REOPEN_EQUILIBRIUM_R : } & 1.0073471671122585 \\ \text { FALL_R_MULTIPLIER : } & 1.0020627766084023\end{array}$

According to the simulation, the final numbers according to Figure 6 and 7 will be 106,470,003 total cases with 201,227deaths. The number of individuals considered "infectious" would be around 53,253,002, while the number of people considered "super infectious" would be around 21,294,001.

Figure 8 shows the values provided in the simulation. In particular, the indicators INITIAL_R_0 has been set to 2.01, LOCKDOWN_R_0 has been set to 0.827854776743376, REOPEN_SHIFT_DAYS has been set to 29.917149850153365, and MORTALITY_RATE has been set to 0.004999999999999999. The rest of the indicators were left on their default values, either due to the value still being accurate to the United States or lacking evidence to change the respective values.

The indicators INITIAL_R_0, LOCKDOWN_R_0, and REOPEN_SHIFT_DAYS values are reflective of the values existing for Canada through COVID19 Projections. I believe that the basic reproduction number (INITIAL_R_0) and post-mitigationeffective reproduction number (LOCKDOWN_R_0) would have been similar to Canada due to Canada's initial protocols ofhow to handle immigration along with implementations of lockdowns. Also, a number of characteristics shared between Canada and the United States would make the spread of the coronavirus similar to one another.

The MORTALITY_RATE value is reflective of the value from South Korea. I believe that the infection fatality rate (MORTALITY_RATE) would have been near the value that President Obama would have achieved during office. As SouthKorea increased their production of personal protective equipment along with screening and testing in the advent of the coronavirus, these actions are what helped identify individuals who got infected early on. These are similar actions reflectivein Obama's pandemic playbook, in which the playbook also mentions that the United States would increase the creation of medical equipments, research towards developing vaccines, and implement any other measures necessary to save lives proactively based on the recommendation of scientific experts (Debendetti, 2020; Shaw, 2020; Kim, An Oh, Oh, \& Lee, 2021; Executive Office of the President of the United States).

\section{Comparison between Trump's Real Numbers and Simulation}

When looking at the values generated, it is important to understand how accurately the COVID19 projection's simulation reflects the number of COVID infections and deaths during Trump's presidency. By creating a comparison between the realvalues reported by the $\mathrm{CDC}$ along with the corrected values that estimate the amount of underreporting that occurs, and thesimulation values, we can see the similarities and differences that exist. 
Table 1. Trump's Real Value vs. Simulation Values

\begin{tabular}{|l|l|l|}
\hline & Real Values & Simulation Values \\
\hline Infections & $\begin{array}{l}\text { CDC Value: } 25,321,092 \\
\text { Corrected Value: } 75,963,276\end{array}$ & $\begin{array}{l}\text { Total Infections: } 132,587,883 \\
\text { Infectious: } 66,293,492 \\
\text { Super Infectious: } 26,517,577\end{array}$ \\
\hline Deaths & $\begin{array}{l}\text { CDC Value: } 424,323 \\
\text { Corrected Value: } 652,805\end{array}$ & 918,871 \\
\hline
\end{tabular}

In regards to infections, the correct value found during President Trump is anticipated to be 75,963,276. When looking at total infections, it may seem that $132,587,883$ is significantly different. That being stated, it is a feasible value due to limitedCOVID testing. The lack of testing has caused these tests to only be implemented with those who have moderate to severe symptoms, leading to a substantial underestimation for the number of people who have been infected (Wu, Mertens, Crider, et. al., 2020). The simulation's value makes this a greater possibility when comparing the corrected value to the simulation's “Infectious" numbers, 75,963,276 compared to 66,293,942, which displays the difference between the two numbers being less than 10 million.

When it comes to deaths, the figures do diverge a bit more. With the correct value, it currently shows a value of 652,805 in comparison to the simulation's value, 918,871. Initially, the difference of around 250,000 in the context of deaths may seem significant, but this discrepancy can be particularly attributed to the underestimation of the reports. During the initial onset ofthe COVID-19 along with various issues that each state faced, many states may have not reported COVID-19 deaths as such, or have been exacerbated by logistical issues when reporting the deaths (Beusekom, 2020; Boyle, 2021).

\section{Analysis: Comparison between Trump Simulation and Obama Simulation}

When generating the values through the COVID19 Projection's simulation between Trump and Obama, this allows us tocreate a baseline expectation that if there are certain issues in the simulation, they will consistently be applied to both scenarios.

Table 2. Trump's Simulation Value vs. Obama's Simulation Values

\begin{tabular}{|l|l|l|}
\hline & Trump's Simulation Values & Obama's Simulation Values \\
\hline Infections & $\begin{array}{l}\text { Total Infections: } 132,587,883 \\
\text { Infectious: } 66,293,492 \\
\text { Super Infectious: } 26,517,577\end{array}$ & $\begin{array}{l}\text { Total Infections: } 106,470,003 \\
\text { Infectious: } 53,253,002 \\
\text { Super Infectious: } 21,294,001\end{array}$ \\
\hline Deaths & 918,871 & 201,227 \\
\hline
\end{tabular}

When analyzing the infections, it becomes evident that Obama's infection rate would have been less, but not by large margins. It may be due to the fact that the United States having dense population areas along with a generally larger population would have made it difficult to contain the infections, especially in comparison to smaller countries. While it maybe the case that the federal government may mandate specific measures, the division between federal and state management may still cause issues when trying to stop the spread of the virus. 
The important difference occurs when regarding deaths. There is a significant difference in the number of deaths, in which the 918,871 deaths under Trump's administration is around 4.5 times greater than the 201,227 deaths under Obama's administration. I anticipate these values to be accurate based on the fact that compared to Trump's administration who did notproactively prepare for the coronavirus, Obama's administration would have taken aggressive measures to be prepared in supplies once they heard, early on, about the spread of the virus. Not only is it outlined in Obama's pandemic playbook regarding communicating, preparing, and distributing supplies needed to fight the virus, but it is also something that Obama recognized needs to be done as quickly as possible after the delays in vaccine development of the H1N1 virus. An aggressivemeasure to slow down the spread of the coronavirus during the advent of the spread would have significantly reduced the mortality rates that would have occurred (Sebenius \& Sebenius, 2020). Particularly, hospitals would have less likely been overwhelmed with lack of space for COVID patients and lack of supplies, factors that exacerbated the ability for doctors to aid COVID patients (Abelson, 2020; Finkenstadt, Handfield, \& Guinto, 2020; Meyer \& Madrigal, 2020).

\section{Limitations}

Through this study, there are limitations that exist when addressing particular actions and decisions that President Obama would have made after the H1N1 pandemic. For example, President Obama most likely would have limited travel, implemented different quarantine protocols, and utilized Executive Orders in order to address any lack of supplies or other issues that arise from the coronavirus. That being stated, it is difficult to state with certainty how fast President Obama wouldhave taken these measures. Also, it is hard to anticipate if and when President Obama would have implemented lockdowns ortravel restrictions, especially when he is cognizant of the potential panic and concern that such a federal mandate would bringto people. These are factors that can significantly influence the numbers that I found through the simulation, as earlier actionscould have prevented even more infections and deaths from occurring. While it is possible to reflect this in the values inputted through the simulation, I decided to not make assumptions on whether President Obama would have taken particularactions to ensure accuracy of the data.

The other limitation that applied is the countries I were able to use as benchmarks to compare with the United States. While Canada and South Korea were used as benchmarks, both countries have particular differences in comparison to the United States that make them not the most perfect measures. If there was a country that mimics more properties to the United States in regards to population size, policies, and various other indicators, I would have been able to use that particular country's values through the simulation to get a more accurate assessment of how President Obama would have performed. These small factors can contribute quite a bit to differences in how fast countries can contain the coronavirus, especially consideringthat the culture that exists in the east like South Korea are more receptive to face masks compared to their western counterparts (Wong, 2020).

\section{Conclusion}

In the end, the true tragedy I must face as a nation is the number of people who died from the coronavirus. With the current numbers of deaths from COVID-19 surpassing 500,000, the United States has come into the spotlight as the case scenario ofhow to not react to the pandemic (Ansari, 2021). In particular, it emphasizes the necessity for the United States to reflect andfind ways in order to prevent such a tragedy from happening again. This is in wake of multiple sources and historical data showing that there will be another pandemic -- the only uncertainty is when (Aizenman, 2020; Constable \& Kushner; Gill, 2020).

By showing the potential number of COVID cases and deaths in between Trump and Obama, it made clear that a significant number of people's lives could have been saved in the beginning of the outbreak. By having stronger leadership and trust in the scientific community, a proactive approach based on testing, contact tracing, and research would have slowed down the spread of the coronavirus along with equipped hospitals with the necessary tools in order 
to save lives. It has become evidentthat politics and presidential influence became a large factor in how the CDC responded to the pandemic, and became the central focus of our recommendation.

This may be due to CDC's apolitical stance, as the health agency has been deliberate in distancing itself from the political scene (Florko, 2020). While it is the case that CDC should be apolitical when dealing with scientific information and actions, the CDC needs to have stronger influence in dictating actions regarding the public's health, rather than purely relying on the US Department of Health and Human Services (HHS). It may become necessary that there needs to be structural changes in the government and CDC, to allow the opportunity of CDC to have influence regarding measures that can be taken. While it may be difficult to envision exactly how to implement these changes, it is important to start conversations and implement changes so that politics is unable to significantly influence agencies like the CDC in dealing with health emergencies likeCOVID-19.

It is difficult discussions like this that will allow America to truly grow as a nation, to create proactive and preventativemeasures from allowing more lives from being lost. As the world is working towards distributing vaccines along with building herd immunity, we can continue to work towards a stronger, more united, future.

\section{Acknowledgments}

I would like to sincerely thank Mr. Brian Oh for mentoring and teaching me through my research journey.

\section{References}

1. Abelson R. (2020, November 28). How US Hospitals Are Stretched Way Too Thin Due to Covid-19. The New York Times. (Accessed at https://www.nytimes.com/2020/11/27/health/covid -hospitals-overload.html)

2. Aizenman N. (2020, February 20). New research: Bats harbor hundreds of coronaviruses, and spillovers aren't rare. NPR. (Accessed at https:/www.npr.org/sections/goatsandsoda/2020/02/20/807742861/new-researchbats-harbor-hundreds-of-coronaviruses-and-spillovers-arent-rare?

3. Ansari T. (2021, February 23). U.S. Covid-19 Death Toll Exceeds Half Million. WSJ. (Accessed at https:/www.wsj.com/livecoverage/covid-2021-02-22/card/AqyUIjgaxETIrN5s2iRs)

4. Angulo, F. J., Finelli, L., \& Swerdlow, D. L. (2021). Estimation of US SARS-CoV-2 INFECTIONS, Symptomatic Infections, hospitalizations, and Deaths Using Seroprevalence surveys. JAMA Network Open, 4(1). doi:10.1001/jamanetworkopen.2020.33706

5. Areddy JT. (2020, May 26). China Rules Out Animal Market and Lab as Coronavirus Origin. Wall Street

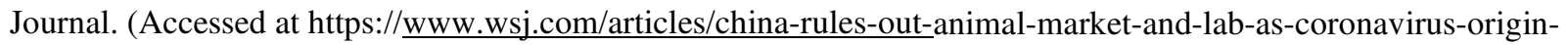
11590517508)

6. Austen I. (2020, September 14). Two Medical Systems, Two Pandemic Responses. The New York Times. (Accessed at https://www.nytimes.com/2020/05/01/world/canada/america-canada-coronavirus-comparison.html)

7. Azralon T. (2020, August 10). What the rest of the world can learn from South Korea's COVID-19 response: Researcher investigates how South Korean policy enabled the country to flatten the curve without economic disaster. ScienceDaily. (Accessed at www.sciencedaily.com/releases/2020/08/200810141006.htm) 
8. Baccini, L., Brodeur, A., \& Weymouth, S. (2020). The COVID-19 pandemic and US presidential elections. doi:10.31222/osf.io/sxajv

9. Baker P. (2020, May 15). Trump Turns to an Old Ploy During Coronavirus Pandemic: Blame Obama. The New York Times. (Accessed at https:/www.nytimes.com/2020/05/14/us/politics/trump-obama.html)

10. Beauchamp Z. (2020, May 4). US versus Canada on coronavirus: Trump failed, Trudeau succeeded. Vox. (Accessed at https:/www.vox.com/2020/5/4/21242750/coronavirus-covid-19-united-states-canada-trump-trudeau)

11. Bennett B. (2020, November 18). COVID-19 Is Spiking—and Donald Trump Has Pulled a "Disappearance Act.” Time. (Accessed at https://time.com/5912675/donald-trump- president-covid-19/)

12. Beusekom M. (2020, July 1). About 30\% of COVID deaths may not be classified as such. CIDRAP. (Accessed at https://www.cidrap.umn.edu/news-perspective/2020/07/about-30-coviddeaths-may-not-be-classified-such)

13. Boyle P. (2021, February 18). How are COVID-19 deaths counted? It's complicated. AAMC. (Accessed at https://www.aamc.org/news-insights/how-are-covid-19-deaths-counted-it -s-complicated)

14. Bruggeman L, Margolin J, Mosk M. (2020, July 29). "They didn't run the plays": Ex-officials say Trump administration didn't use pandemic "playbooks.” ABC News. (Accessed at https://abcnews.go.com/Health/runplays-officials-trump-administration-pandemic-playbooks/story?id=71999769)

15. Carvajal N. (2020, May 15). US coronavirus update: Latest on cases, deaths and reopening. CNN. (Accessed at https://edition.cnn.com/us/live-news/us-coronavirus-update-05-15-20/ h_5987b61087f263efd96fd433de24f0a4)

16. Cases, Data, and Surveillance. (2020, February 11). Centers for Disease Control and Prevention. (Accessed at https:/www.cdc.gov/coronavirus/2019-ncov/cases-updates/about-epidemiology/identifying-sourceoutbreak.html)

17. CDC. (2020, March 28). COVID Data Tracker. Centers for Disease Control and Prevention. (Accessed at https://covid.cdc.gov/covid-data-tracker/\#trends totalandratecasestotalrate)

18. Chehrehgosha M. (2020, June 6). The Unpreparedness of the Healthcare System for the Management of COVID-19 Pandemic Leading to the Mistreatment of the Elderly: A Newly Emerging Moral Dilemma. PubMed Central (PMC). (Accessed at https://www.ncbi.nlm.nih.gov/pmc/articles/PMC7275658/)

19. Chen C. (21-07-20). How to Understand COVID-19 Numbers. Propublica. (Accessed at https:/www.propublica.org/article/how-to-understand-covid-19-numbers)

20. CNN.com Wire Service. (2020, May 12). Fact check: Obama left Trump a pandemic response playbook. The Mercury News. (Accessed at https:/www.mercurynews.com/2020/05/12/fact-check-obama-left-trump-apandemic-response-playbook) 
21. Coletta A. (2020, July 15). Canada's coronavirus performance hasn't been perfect. But it's done far better than the U.S. The Washington Post. (Accessed at https:/www.washingtonpost.com/world/the americas/coronavirus-canada-united-states/2020/07/14/0686330a-c14c11ea-b4f6-cb39cd8940fb_story.html)

22. Collman C. (2020, March 17). In 2017, Obama officials briefed Trump's team on dealing with a pandemic like the coronavirus. One Cabinet member reportedly fell asleep, and others didn't want to be there. Business Insider. (Accessed at https://www.businessinsider.nl/trump-appointees-trained-pandemic-response-in2016-2020-3? international=true\& $\mathrm{r}=\mathrm{US}$ )

23. Constable H, Kushner J. (2021). Stopping the next one: What could the next pandemic be? BBC Future. (Accessed at https://www.bbc.com/future/article/20210111-what-could-the-nextpandemic-be)

24. Department of Health and Human Services. (2020, September). Department of Health and Human Services (HHS) Crimson Contagion 2019 Functional Exercise After-Action Report, 2020. https://www.governmentattic.org/38docs/HHSaarCrimsonContAAR 2020.pdf

25. Debenedetti G. (2020, March 12). Obama's Ebola Czar, Ron Klain, on How Trump Has Bungled the Coronavirus Response. Intelligencer. Accessed at https://nymag.com/intelligencer/2020/03/obamasebola-czar-on-how-trump-bungled-coronavirus-response.html)

26. Dornauer, M. (2020, August 6). Why Was America So Unprepared for the COVID-19 Pandemic? Medium. (Accessed at https://freopp.org/why-was-america-so-unprepared-for- the-covid-19-pandemic-8c0602a971ec)

27. Evon, D. (2020, March 2). Did Obama Declare Swine Flu an Emergency Only After 'Millions' Were Infected? Snopes. (Accessed at https://www.snopes.com/fact-check/obama-wait-swine-flu-n1h1/.)

28. Executive Office of the President of the United States. (2016). Playbook for Early Response to HighConsequence Emerging Infectious Disease Threats and Biological Incidents. https://assets.documentcloud.org/documents/6819268/Pandemic-Playbook.pdf

29. Fabian J. (2020, June 25). Now, Trump blames Obama and Biden for all the crises he's facing. ThePrint. (Accessed at https://theprint.in/world/now-trump-blames-obama-and-biden-for-all-the-crises-hes-facing/448790/.)

30. Farzan, A. N., Hassan, J., Bellware, K., O’Grady, S., Hawkins, D., Beachum, L., Shaban, H., Kornfield, M., \& Iati, M.(2020, August 14). U.S. was 'unprepared' for 'greatest public health crisis' in a century, CDC director says. Washington Post. (Accessed at https://www.washingtonpost.com/nation/2020/08/13/coronavirus-covid-liveupdates-us/.)

31. Finkenstadt, D. J., Handfield R., \& Guinto, P. (2021, February 2). Why the U.S. Still Has a Severe Shortage of Medical Supplies. Harvard Business Review. (Accessed at https://hbr.org/2020/09/why-the-u-s-still-hasa-severe-shortage-of-medical-supplies)

32. Fitzpatrick, A. (2020, August 13). Why the U.S. Is Losing the War on COVID-19. Time. (Accessed at https://time.com/5879086/us-covid-19/) 
33. Florko, N. (2020, July 13). The CDC is an apolitical island. That's left it defenseless against Trump. STAT. (Accessed at https://www.statnews.com/2020/07/13/cdc-apolitical-island-defenseless/)

34. Global Health Security Index. (2020, April 10). Findings and Recommendations. GHS Index. (Accessed at https://www.ghsindex.org/.)

35. Gill, B. V. (2020, June 6). Coronavirus: This is not the last pandemic. BBC News. (Accessed at https://www.bbc.com/news/science-environment-52775386)

36. Gingrich, N. (2020, March 26). Newt Gingrich: How China Mismanaged and Lied About CoronavirusThen Blamed America | Opinion. Newsweek. (Accessed at https://www.newsweek.com/newt-gingrich-how-chinamismanaged-lied-about-coronavirusthen-blamed-america-opinion-1494532)

37. Gu, Y. (2020, April). COVID-19 Projections Using Machine Learning - covid19-projections.com. COVID19 Projections Using Machine Learning. https://covid19-projections.com

38. Haseltine, W. A. (2020, November 4). Lancet Study Suggests U.S. Is Massively Undercounting Covid-19 Cases. Forbes. (Accessed at https:/www.forbes.com/sites/williamhaseltine/2020/11/04/every-day-one-millionamericans-likely-infected/?sh=1b 430db26456)

39. Radcliffe, S. (2020, August 10). Here's What Happened the Last Time We Had a Vaccine During a Pandemic. Healthline. (Accessed at https://www.healthline.com/health-news/what-happened-the-last-time-we-hada-vaccine-during-a-pandemic)

40. Hitti, M. (2009, April 26). Swine Flu: U.S. Declares Public Health Emergency. WebMD. (Accessed at https://www.webmd.com/cold-and-flu/news/20090426/swine flu 20 us cases confirmed)

41. Homeland Security Council. (2005, November). National Strategy for Pandemic Influenza. (Accessed at https://www.cdc.gov/flu/pandemic-resources/pdf/pandemic-influenza-strategy-2005.pdf.)

42. Jankowicz, M. (2020, October 26). A new memoir from Barack Obama describes how he developed a pandemic playbook for the US, which Trump went on to ignore. Business Insider. (Accessed at https:/www.businessinsider.com/obama-book-recalls-developing-pandmic-response-plan-that-trump-ignored-202010 ?international $=$ true $\& \mathrm{r}=\mathrm{US} \& \mathrm{IR}=\mathrm{T})$

43. Keller, J. (2020, March 20). Why the US government was unprepared for COVID-19, according to a biodefense expert. Task \& Purpose. (Accessed at https://taskandpurpose.com/analysis/national-biodefense-strategycoronavirus-covid-19/)

44. Khan, H., \& Fletcher, L. (2009, October 26). H1N1 Vaccine Shortages Create Panic, Worry. ABC News. (Accessed at https://abcnews.go.com/GMA/OnCall/swine-flu-h1n1-flu-vaccine-shortage-panic/story?id=8915650) 45. Kim, J. H., An, J. A. R., Oh, S. J. J., Oh, J., \& Lee, J. K. (2021, March 5). Emerging COVID-19 success story: South Korea learned the lessons of MERS. Our World in Data. (Accessed at https://ourworldindata.org/covidexemplar-south-korea) 
46. Woolhandler, S., Himmelstein, D. U., Ahmed, S., et al. (2021, February 20). Public policy and health in the Trump era. The Lancet. (Accessed at https://www.thelancet.com/journals/lancet/article/PIIS0140-6736(20)325459/fulltext)

47. Levin, B. (2020, February 11). Trump Claims Coronavirus Will "Miraculously" Go Away by April. Vanity Fair. (Accessed at https:/www.vanityfair.com/news/2020/02/donald-trump-coronavirus-warm-weather)

48. Lister, S.A., Redhead, C.S. (2009, September 10). The 2009 Influenza Pandemic: An Overview. Congressional Research Service. Doi: 7-6700 / R40554.

49. Lockhart, O. B. J. (2020, November 2). Opinion: The Covid-19 lessons Trump didn't learn. CNN. (Accessed at https://edition.cnn.com/2020/11/02/opinions/donald-trump-covid-lessons-election-lockhart/index.html)

50. Lovelace, B. (2020, July 14). Drugmakers will start coronavirus vaccine production by end of summer, Trump health officials say. CNBC. (Accessed at https://www.cnbc.com/2020/07/13/drugmakers-will-startcoronavirus-vaccine-production-by-end-of-summer-trump-health-officials-say.html)

51. Macias, A. (2020, December 31). Trump boasts about his Covid response after largely ignoring crisis during deadliest month yet. CNBC. (Accessed at https://www.cnbc.com/2020/12/31/trump-boasts-about-covidresponse-as-december-becomes-deadliest-month-yet.h tml)

52. Mallapaty, S. (2020, November 11). Where did COVID come from? WHO investigation begins but faces challenges. Nature. (Accessed at https:/www.nature.com/articles/d41586-020-03165-

9? error $=$ cookies not supported\&code $=38765$ ff5-b33e-4b9f-93 e2-e8de50f081a4)

53. Martin, T.W. \& Yoon, D. (2020, September 25). How South Korea Successfully Managed Coronavirus. Wall Street Journal. (Accessed at https://www.wsj.com/articles/lessons-from-south-korea-on-how-to-manage-covid$\underline{11601044329 .)}$

54. Meyer, R., \& Madrigal, A. C. (2020, December 4). The U.S. Has Passed the Hospital Breaking Point. The Atlantic. (Accessed at https://www.theatlantic.com/health/archive/2020/12/the-worst-case-scenario-is-happeninghospitals-are-overwhelmed/617301/.)

55. Moore, J. (2020, November 07). Trump would have easily won a second term if it weren't FOR COVID-19. Independent. (Accessed at https://www.independent.co.uk/voices/trump-us-election-coronavirus-second-termb1667035.html.)

56. Moore, E. (2020, October 16). Trump's and Biden's plans on The Coronavirus Pandemic. NPR. (Accessed at https://www.npr.org/2020/10/16/919139204/trumps-and-biden-s-plans-on-the-coronavirus-pandemic.)

57. Mosk, M. (2020, April 5). George W. Bush in 2005: 'If we wait for a pandemic to appear, it will be too late to prepare'. ABC News. (Accessed at https://abcnews.go.com/Politics/george-bush-2005-wait-pandemic-lateprepare/story?id=69979013\&cid=social_fb_abcn.)

58. Naylor, B. (2009, May 07). Obama Flu Response Relied On Bush Plan. NPR. (Accessed at https:/www.npr.org/templates/story/story.php?storyId=103908247.) 
59. Noh, J., \& Danuser, G. (2020). Estimation of the fraction of COVID-19 infected people in U.S. States and countries worldwide. doi:10.1101/2020.09.26.20202382

60. Obama, B. (2020). A Promised Land. New York: Penguin Random House.

61. Parker, A., Dawsey, J., Viser, M., \& Scherer, M. (2020, November 07). How Trump's erratic behavior and failure on coronavirus doomed his reelection. The Washington Post. (Accessed at https://www.washingtonpost.com/elections/interactive/2020/trump-pandemic-coronavirus-election/.)

62. Paz, C. (2020, November 2). All the President's lies about the Coronavirus. The Atlantic. (Accessed at https://www.theatlantic.com/politics/archive/2020/11/trumps-lies-about-coronavirus/608647/.)

63. Peters, C. (2020, June 8). A detailed timeline of all the ways Trump failed to respond to the coronavirus. Vox. (Accessed at https://www.vox.com/2020/6/8/21242003/trump-failed-coronavirus-response.)

64. Public Health Agency of Canada. (2020, June 29). Update on COVID-19 in Canada: Epidemiology and Modelling. (Accessed at https://www.canada.ca/content/dam/phac-aspc/documents/services/diseasesmaladies/coronavirus-disease-covid-19/epidemiological-economic-researchdata/update_covid_19_Canada_epidemiology_modelling_29june2020.pdf.)

65. Reinhard, B., Brown, E., Thebault, R., \& Sun, L. H. (2020, June 08). CDC wants states to count 'PROBABLE' coronavirus cases and deaths, but most aren't doing it. The Washington Post. (Accessed at https://www.washingtonpost.com/investigations/cdc-wants-states-to-count-probable-coronavirus-cases-and-deaths-b ut-most-arent-doing-it/2020/06/07/4aac9a58-9d0a-11ea-b60c-3be060a4f8e1_story.html.)

66. Sebenius, I. \& Sebenius, J.K. (2020, June 19). How many needless Covid-19 deaths were caused by delays in responding? Most of them. Stat. (Accessed at https://www.statnews.com/2020/06/19/faster-response-preventedmost-us-covid-19-deaths/.

67. Shaw, A.R. (2020, May 17). How President Barack Obama Would Have Handled COVID-19. Bluefield Media, LLC.

68. Schnirring, L. (2009, October 26). Obama's emergency STEP aimed to help implement disaster plans. CIDRAP. (Accessed at https://www.cidrap.umn.edu/news-perspective/2009/10/obamas-emergency-step-aimedhelp-implement-disaster-pla ns.)

69. The White House. (2009, October 24). Declaration of a National Emergency with Respect to the 2009 H1N1 Influenza Pandemic. (Accessed at https://obamawhitehouse.archives.gov/realitycheck/the-pressoffice/declaration-a-national-emergency-with-respect-2009-h1n1-influenza-pandemic-0.)

70. The White House. (2015, July 28). Fact Sheet: The Global Health Security Agenda. (Accessed at https://obamawhitehouse.archives.gov/the-press-office/2015/07/28/fact-sheet-global-health-security-agenda.)

71. Guardian staff and agencies. (2020, November 22). Donald Trump appears to admit COVID is 'running wild' in the US. The Guardian. (Accessed at https://www.theguardian.com/us-news/2020/nov/22/donald-trumpappears-to-admits-covid-is-running-wild-in-the-us.) 
72. United States Congressman Lloyd Doggett. (2021, January 20). Timeline of Trump's Coronavirus Responses. (Accessed at https://doggett.house.gov/media-center/blog-posts/timeline-trump-s-coronavirusresponses.)

73. Walsh, N. P. (2020, December 01). The Wuhan files: Leaked documents reveal China's mishandling of the early stages of Covid-19. CNN News. (Accessed at https:/www.cnn.com/2020/11/30/asia/wuhan-china-covidintl/index.html.)

74. William Natcher Center \& National Institute of Health. (2005, November 01). President Outlines Pandemic Influenza Preparations and Response. (Accessed at https://georgewbushwhitehouse.archives.gov/news/releases/2005/11/20051101-1.html.)

75. Wong, C. (2020, April 19). Asian countries more receptive to China's coronavirus 'face mask diplomacy'. South China Morning Post. (Accessed at https://www.scmp.com/news/china/diplomacy/article/3080406/asiancountries-more-receptive-chinas-coronavirus-f ace-mask.)

76. Wu, S. L., Mertens, A., Crider, Y. S., Nguyen, A., Pokpongkiat, N. N., Djajadi, S., Seth, A., Hsiang, M.S., Colford Jr., J.M., Reingold, A., Arnold, B.F., Hubbard, A., \& Benjamin-Chung, J. (2020). Substantial underestimation of SARS-CoV-2 infection in the United States. doi:10.1101/2020.05.12.20091744

77. VCU Health. (2020). Comparing COVID-19 with H1N1 and other viral outbreaks. (Accessed at https:/www.vcuhealth.org/news/covid-19/comparing-covid-19-with-h1n1-and-other-viraloutbreaks\#: :text=The $\% 20$ major $\% 20$ difference $\% 20$ from $\% 20$ SARS,coronavirus $\% 20$ is $\% 20$ much $\% 201$ ess $\% 20 d$ deadly .)

78. Viglione, G. (2020, November 03). Four ways Trump has meddled in pandemic science - and why it matters. Nature. (Accessed at https:/www.nature.com/articles/d41586-020-03035-4.)

79. Yan, W., \& Babe, A. (2020, October 05). What Should the U.S. Learn from South Korea's Covid-19 Success? Undark. (Accessed March 12, 2021, at https://undark.org/2020/10/05/south-korea-covid-19-success/.)

80. Yong, E. (2020, August 06). How the Pandemic Defeated America. The Atlantic. (Accessed at https://www.theatlantic.com/magazine/archive/2020/09/coronavirus-american-failure/614191/.) 